\title{
Determination of Rationalization in EPC Mode and its Incentive Mechanism Research
}

\author{
Shumin Li \\ Department of Industrial Engineering, Tianjin University of Technology, Tianjin, 300384, China \\ 1375861492@qq.com
}

Keywords: Rationalization of the proposed scope; Reduce the cost of the employer; To shorten the construction period

\begin{abstract}
EPC project general contracting model to high-speed, low-cost construction of high-rise buildings and large-scale industrial projects and become the international construction projects widely used in one of the general contracting. With the development of the "one side" strategy, the EPC general contracting model of design and construction procurement has been vigorously promoted in China. EPC mode, the contractor is responsible for the design, construction, procurement, and its quality, safety, duration, cost fully responsible. The contractor advises the contractor to reduce the cost of the project, shorten the construction period and benefit both parties. This paper uses the method of literature analysis to define the main situation of the rationalization proposal of the contractor in the existing research, and make a quantitative study on the incentive amount of the contractor's rationalization proposal to reduce the cost of the contractor.
\end{abstract}

\section{Introduction}

Since the project general contracting mode was introduced into our country in the 1980s, it has been approved by all parties. Many engineering companies, industries and colleges and universities have conducted many discussions on the theory and practice of the project general contracting mode. In 2016, the Ministry of Housing and Urban-Rural Development promulgated "Several Opinions on Further Promoting the Development of General Contracting Projects", which put forward further requirements on the management of general contracting projects. You can see that you are the trend of the general contract contracting mode. The existing literature also did not summarize the main situations of the rationalization proposal under the EPC mode and did not define the scope of the rationalization proposal. Therefore, in the actual operation of EPC project, the Employer lacked the basis and principle of judgment, The rationalization proposal is difficult to define, to a certain extent, hinder the implementation of the rationalization proposal and the mutual benefit and win-win result of both parties.

Based on FIDIC Contract Conditions for Designing Procurement and Construction (EPC) Project and Model Demonstration Contract of General Construction Project, this paper studies the following aspects in determining the scope of reasonable suggestions for contractors under EPC mode and its incentive mechanism.

\section{Existing defects analysis of rationalization proposal and incentive mechanism in EPC mode}

\section{Reasonable proposal of the amount of incentives to set the standard is not clear}

The FIDIC Silver Book does not refer to the award amount standard. The "Model Contract of General Construction Contract" also only states that "the benefit sharing should be carried out according to the stipulations in the special provisions. If necessary, the two parties may sign the supplemental benefit sharing agreement as an annex to the contract." These provisions are difficult to meet the implementation requirements of the implementation of the EPC project, there is no reference to set the standard award amount, the two sides generally agreed in the contract contract 
rationalization of incentives, as EPC projects are mostly large industrial investment projects, the main Concentrating on petroleum, chemical industry, metallurgy and power engineering, the uncertainty is high and the contractor assumes most of the risks. If a reasonable amount of rewards is set, this will easily lead to unfair distribution of profits between the contracting parties and strike down the enthusiasm of contractors to put forward rational proposals. Setting a reasonable standard amount of reward is a problem to be solved.

\section{Rationalization proposals related research is still not enough}

The rationalization proposal and its related concepts are searched and the literature is analyzed according to the research contents, and the results are shown in Table 1

Table 1 rationalization studies table of contents

\begin{tabular}{|c|c|c|}
\hline $\begin{array}{c}\text { Serial } \\
\text { number }\end{array}$ & author & $\begin{array}{l}\text { The main research contents about the rationalization proposal of the } \\
\text { contractor }\end{array}$ \\
\hline 1 & Zhang Наo ${ }^{[1]}$ & $\begin{array}{l}\text { 1. Contractor to propose changes in the approval of the approval process } \\
\text { 2. The design phase of the contractor to determine the scope of the } \\
\text { proposed change } \\
\text { 3. Improve the approach to change the procedure }\end{array}$ \\
\hline 2 & Wang Yuming ${ }^{[2]}$ & $\begin{array}{l}\text { 1. Suggested changes in the concept of definition } \\
\text { 2. Proposed change approval procedures } \\
\text { 3. The contractual distribution of the interests of both parties }\end{array}$ \\
\hline 3 & sheets of water waves $^{[3]}$ & Design optimization changes caused by claims \\
\hline 4 & Sun Kensheng ${ }^{[4]}$ & contractor recommended change scope to determine principle \\
\hline 5 & Liu Yuke ${ }^{[5]}$ & The amount of benefit-sharing that the contractor proposes to change \\
\hline 6 & Zhao Dong song ${ }^{[6]}$ & $\begin{array}{l}\text { 1. Contractor to change the amount of benefit-sharing } \\
\text { 2. Benefits of benefit sharing } \\
\text { 3. The reasons for the lack of motivation for the proposed change }\end{array}$ \\
\hline 7 & Wang Bo et al ${ }^{[7]}$ & design stage, reduce the optimization program was risk-taking approach \\
\hline
\end{tabular}

Source: Draw on your own

In summary, different scholars study the rationalization proposals in EPC mode from different perspectives. They mainly include the conceptual definition of reasonable suggestions, the definition of scope, the approval control procedures, the provisions of the incentive amount and the advantages of implementing incentive awards. Each scholar only studied the rationalization proposal in a small space. Most of the researches on the proposed change were concentrated in the design stage. The scope of the rationalization proposal and the definition of the rewards amount were not further defined nor quantitatively and qualitatively studied. For the principle of the provisions or only for a specific project to make an agreement, not practical. In response to this article will determine the scope of the rationalization proposals, and rationalization proposals to shorten the duration of the incentive mechanism.

\section{Rationalization of the scope of the proposal}

The term "rationalization proposals" in the field of construction engineering first appeared in the 99 edition of the Construction Contract (Model Text) (GF-1999-0201), and its provision 29.3 stipulated that the rationalization proposal put forward by the contractor in construction involved Changes to the design drawings or construction design and replacement of materials and equipment shall be subject to the approval of the Engineer. The engineer agrees to adopt the suggestion of rationalization of the contractor, the expenses incurred and the gains obtained, and the contractor of the subcontractor shall otherwise agree to share or share.

Different domestic and international contract texts may have different names for clauses concerning the contents of rationalization proposals such as "Construction Contract Conditions" (hereinafter referred to as "FIDIC Red Book") and "Contract Conditions for Design Procurement Construction (EPC)" (hereinafter referred to as "FIDIC Silver Paper Book ") the terms of the name of the" value engineering "," construction project EPC contract model text "the title of the article is" 
the proposed change of rights. "

\section{The Use of Rational Proposals by Contractors under Value Engineering Theory}

"Value Engineering" is a concept in engineering economics that studies how to optimize the function / cost ratio so that the amount of input costs can play its best role. The FIDIC Silver Paper attributes the rationalization proposal to the clause "Value Engineering "Under the terms of the provisions.

As the concrete executor of the project and the owner of the professional ability, the contractor can help the owners to reduce the construction cost and bring more benefits to the project by making reasonable suggestions to the owners. Therefore, in the EPC project contract, the relevant provisions of the reasonable suggestion incentive mechanism are often added to encourage EPC contractors to put forward rational proposals as much as possible to the owners to help the project owners raise the project value so as to benefit both parties. This content is introduced into the project contract.

\section{Contractor rationalization proposals to shorten the duration of the incentive mechanism}

Under the EPC mode, one of the effects of the contractor rationalization proposal is to shorten the construction period. There is no quantitative regulation for the FIDIC silver paper and the demonstration text of the EPC contract for the construction project. Due to different modes Shorten the duration of the reward method in principle is the same, so the following documents related to shorten the duration of the incentive mode of analysis for the owners in practice reward points into a clear direction, the analysis results shown in Table 2. 
Table 2 the provisions of normative documents for shortening the awards

\begin{tabular}{|c|c|c|c|}
\hline file name & Reward & Cardinality & Reward way \\
\hline $\begin{array}{l}\text { Construction project } \\
\text { inventory pricing } \\
\text { specification } \\
\text { (GB50500-2013) }\end{array}$ & $\begin{array}{l}\text { The contracting parties shall agree on the amount to be } \\
\text { compensated for each calendar day completed in advance. } \\
\text { This fee should be included in the final settlement } \\
\text { document as an increase in the contract price and should be } \\
\text { paid in conjunction with the settlement }\end{array}$ & - & $\begin{array}{l}\text { Daily } \\
\text { calendar } \\
\text { days }\end{array}$ \\
\hline $\begin{array}{l}\text { Interim Provisions on } \\
\text { Implementing Early } \\
\text { Completion Award for } \\
\text { Construction Projects }\end{array}$ & $\begin{array}{l}\text { The amount of completion award (penalty) for each } \\
\text { advance (or delay) may be calculated according to the } \\
\text { degree of difficulty in construction and in accordance with } \\
\text { the construction budget cost of two ten thousandths to four } \\
\text { ten thousandths }\end{array}$ & - & $\begin{array}{l}\text { Daily } \\
\text { calendar } \\
\text { days }\end{array}$ \\
\hline $\begin{array}{l}\text { Several Provisions on } \\
\text { Implementing Early } \\
\text { Completion Awards for } \\
\text { Construction Projects }\end{array}$ & $\begin{array}{l}\text { Each advance (or delay) completion of the award (penalty) } \\
\text { amount shall not exceed the construction budget of two ten } \\
\text { thousandths }\end{array}$ & - & $\begin{array}{l}\text { Daily } \\
\text { calendar } \\
\text { days }\end{array}$ \\
\hline $\begin{array}{l}\text { Guangzhou Construction } \\
\text { Contract (2013 } \\
\text { Demonstration Text) }\end{array}$ & $\begin{array}{l}\text { The parties to the contract in the special terms agreed in } \\
\text { advance completion award, a clear daily calendar day } \\
\text { should be awarded }\end{array}$ & - & $\begin{array}{l}\text { Daily } \\
\text { calendar } \\
\text { days }\end{array}$ \\
\hline $\begin{array}{l}\text { Hebei Province construction } \\
\text { contract } 2013 \text { version (model } \\
\text { text) }\end{array}$ & $\begin{array}{l}\text { Employer, the contractor in the special terms of the } \\
\text { agreement in advance to complete the award, agreed daily } \\
\text { calendar day should be awarded }\end{array}$ & - & $\begin{array}{l}\text { Daily } \\
\text { calendar } \\
\text { days }\end{array}$ \\
\hline $\begin{array}{c}\text { Construction Contract of } \\
\text { Sichuan Province (Model } \\
\text { Text) }\end{array}$ & $\begin{array}{l}\text { The parties to the contract in the special terms agreed in } \\
\text { advance completion award, a clear daily calendar day } \\
\text { should be awarded }\end{array}$ & - & $\begin{array}{l}\text { Daily } \\
\text { calendar } \\
\text { days }\end{array}$ \\
\hline $\begin{array}{l}\text { Guangdong Construction } \\
\text { Engineering Standard } \\
\text { Construction Contract (2009 } \\
\text { Edition) }\end{array}$ & $\begin{array}{l}\text { The two parties to the contract in the special terms agreed } \\
\text { in advance completion award, a clear calendar day should } \\
\text { be the amount of }\end{array}$ & - & $\begin{array}{l}\text { Daily } \\
\text { calendar } \\
\text { days }\end{array}$ \\
\hline $\begin{array}{l}\text { Beijing Municipality on the } \\
\text { housing renovation project to } \\
\text { implement the } \\
\text { pre-completion award a } \\
\text { number of provisions }\end{array}$ & $\begin{array}{l}\text { For each advance (or delay) day, the total amount of bonus } \\
\text { (penalty) shall be calculated on the basis of five } \\
\text { thousandths of the total salary of the final accounts (and so } \\
\text { on) }\end{array}$ & - & $\begin{array}{l}\text { Daily } \\
\text { calendar } \\
\text { days }\end{array}$ \\
\hline $\begin{array}{l}\text { Yunnan Province, the key } \\
\text { construction projects on the } \\
\text { implementation of incentive } \\
\text { provisions }\end{array}$ & $\begin{array}{l}\text { Take } 10 \% \text { to } 30 \% \text { of the project investment balance as a } \\
\text { bonus. Duration of each } 5 \text { days in advance, the amount of } \\
\text { the corresponding increase of } 1 \text { percentage point (ahead of } \\
\text { schedule increased the amount of the prize does not exceed } \\
10 \text { percentage points) }\end{array}$ & $\begin{array}{c}\text { Investment } \\
\text { balance }\end{array}$ & Accrued \\
\hline $\begin{array}{l}\text { Several Provisions } \\
\text { Concerning the Problem of } \\
\text { Earlier Commissioning of } \\
\text { Electricity Construction } \\
\text { Projects }\end{array}$ & $\begin{array}{l}\text { The commissioning proceeds shall be distributed in the } \\
\text { following proportions: The construction unit of the project } \\
\text { (the construction unit under the bidding contracting project } \\
\text { shall be not less than } 75 \% \text { of the revenue) }\end{array}$ & $\begin{array}{l}\text { Put into } \\
\text { operation ahead } \\
\text { of schedule }\end{array}$ & Accrued \\
\hline
\end{tabular}

Source: Draw on your own

Through the analysis of normative documents in Table 3, there are two calendar days and two accruals to shorten the duration of the project. Among them, the accrued basis is divided into investment balance and advance production proceeds. The daily calendar method is based on the amount of compensation that should be paid by the two parties on a calendar day basis multiplied 
by the number of calendar days. The withdrawal method is based on a certain percentage of the withdrawal basis for compensation.

Table 3 existing literature to shorten the exciting provided

\begin{tabular}{|c|c|c|}
\hline Reward way & Daily calendar days & Accrued \\
\hline Reward calculation method & $\begin{array}{c}\text { Calendar days } \times \text { fixed bonus amount } \\
\text { agreed by both parties }\end{array}$ & Withdrawal ratio $\times$ withdrawal base \\
\hline Ways to pay & Fixed pay & Changes in remuneration \\
\hline The scope of application & $\begin{array}{l}\text { Applicable to a wide range of } \\
\text { non-profit projects and profitability } \\
\text { projects are applicable, that is, the } \\
\text { project operation period with or without } \\
\text { proceeds of the project, operation and } \\
\text { construction are not the same unit } \\
\text { responsible for the project }\end{array}$ & $\begin{array}{l}\text { Need to take into account the } \\
\text { construction phase and operation and } \\
\text { maintenance phase of the project, } \\
\text { mostly for profitability projects }\end{array}$ \\
\hline Contractor satisfaction & Lower & high \\
\hline Incentive effect & Weaker & Strong \\
\hline
\end{tabular}

Source: Draw on your own

As can be seen from Table 3, the method for calculating the reward for the daily calendar days is the number of calendar days $\times$ the fixed reward credits agreed upon by both parties, which is a form of fixed compensation. The withdrawal method is a form of variable reward. For the withdrawal of such incentives in the hair contract between the two parties in the contract state, the contractor will be able to clear their own efforts will be a corresponding degree of return, and in the early stages of cooperation with the outsourcer, a sense of fairness will be enough In terms of social capital, this will also generate trust due to fairness and improve the contract performance.

\section{Conclusion}

Due to the complicated operation of EPC projects and the uncertainties in the process of design, construction and procurement, it is impossible for any construction project to foresee and cover all the possible changes in the project implementation. Therefore, engineering changes are inevitable. The contractor can make reasonable suggestions based on the frequent changes, such as optimizing the design. When the rationalization proposal put forward by the contractor is adopted and the engineering contractor is brought in, the owner should give the appropriate reward, which can encourage the contractor to use his own rich experience to put forward reasonable suggestions in favor of the project value increase and improve the investment of the owner effectiveness. The main research results of this thesis are:

Based on the contract documents, policy documents and existing documents, the article draws the conclusion that the project should shorten the construction period by adopting the comparative analysis method. Shorten the construction period is certainly brought to the owners of the proceeds of production ahead of schedule, based on the principle of excess profit sharing principle, that is, when excess profits are co-created by the efforts of two or more parties, from a shared perspective, all parties should share a certain proportion of excess profit. At the same time taking into account the incentive effect, the contractor rationalization proposals to shorten the duration of the reward should be accrued by way of accrual. 


\section{References}

[1] Zhang Hao. "Change" of International EPC Contract. International Petroleum Economics, 2013, (09): $53 \sim 57+109 \sim 110$.

[2] Wang Yuming. On change management of project construction general contracting project. Manager, 2016, (08): 321 322.

Zhang Shui-bo, Wang Hui-hui, He Bo-sen. Disputes and Claims of EPC General Contracting Project. International Economic Cooperation, 2006, (02): 36 38.

[4] Sun Miansheng. Change and Claims Management under EPC Contract. Coal Engineering, 2013, (12): $139 \sim 141$.

[5] Liu Yuke. "Construction project general contracting contract model text (for Trial Implementation)" composition, structure and terms of the interpretation of the program (on). China Survey and Design, 2011, (11): 7

[6] ZHAO Dongge. The Design and Construction General Contract Management Practice of Ku-A Freeway [D]. Chang'an University, 2014.

[7] Wang Bo. To play a leading role in the design of EPC projects. Petroleum Engineering Construction, 2013, (01): $66 \sim 68+92$.

[8] Meng Xianhai, Jiren Zhu, Zhao Q. Comparison of EPC general contracting mode and traditional mode. International Economic Cooperation, 2004, (11): 49 50.

[9] Chen Yuwei. Analysis of domestic (general contracting company) EPC project management status quo and development direction. Science and Technology Innovation Herald, 2008, (12): 187 $\sim 188$.

[10] Fan Feijun.Application and discussion of EPC project general contracting management in the project.Construction Economy, 2006, (09): $49 \sim 51$. 